\title{
The ECONOMic ImpaCt OF Hunting: A Regional APproach
}

\author{
Petrus van der Merwe and Melville Saayman
}

Tourism Research in Economic, Environs and Society, North-West University

\author{
Riaan Rossouw
}

School of Economics, North-West University

Accepted: May 2014

\begin{abstract}
The core of South Africa tourism industry is based on wildlife tourism. Private game reserves and game farms which forms part of wildlife tourism constitute most of the wildlife products in South Africa. On these private reserves and game farms, hunting is one of the major income generators for product owners. The aim of this study is to analyse the economic impact of hunting on the regional economies of three of South Africa's most important hunting provinces. The study used economic multipliers, input-output analysis, and related modelling processes through input-output (supply-use) tables and social accounting matrices (SAM). The results differed significantly for the three provinces, with Limpopo receiving the biggest impact (R2.6 billion) and the Free State having the highest multiplier (2.08). The geographical location of the game farms, the number of farms per province and the species available all influenced the magnitude of the economic impact of hunters over and above the traditional determinants of economic impact analysis. The implication of the research is that it will help product owners in the development of game farms or hunting products, contribute to policy formulation, especially for government decisions on what products to offer where, and how to create more jobs.
\end{abstract}

Key words: hunting, biltong hunting, trophy hunting, tourism, economic impact, South Africa, social, accounting matrix

JEL: A110, B410, C670

1

\section{Introduction}

Wildlife-based tourism, including hunting, is attracting increasing interest from governments, the tourism industry and researchers alike. Southern and Eastern Africa are renowned as hunting destinations, South Africa being the most favoured (Dorrington, 2005:12, 2007:3). Hunting is an important source of income for the South African wildlife industry (Van der Merwe \& Saayman, 2005:1). The greater part of this industry takes place on privately-owned farms and game reserves, which constitute $17.9 \%$ of the total land suitable for agriculture in South Africa (Damm, 2005; Samuelson \& Stage, 2007; Van der Merwe, 2004). The number of game farms in South Africa has increased sharply since the early 1990s, and at the time of writing was estimated to be more than 9,000 (Boddington, 2010:200; Mabunda, 2008:82). This translates into 14.7 million hectares (Van Hoven, 2005).

A game farm is defined as land that is adequately fenced, contains a variety of species that can be used for hunting, meat production and live game sales, and provides infra- and supra-structures for wildlife tourists (Van der Merwe, Saayman \& Krugell, 2004:106). In South Africa, hunting is primarily of two types, biltong and trophy hunting. Van der Merwe et al. (2004:106) define biltong hunting as a cultural activity, during which wildlife is hunted with a rifle, bow or similar weapon to produce a variety of meat (venison) products, such as biltong and salamis. Biltong is a type of cured meat, the concept of which originated in South Africa. It is made from various types of meat, such as beef and game (biltong is similar to jerky, which is produced in the USA). Trophy hunting is an activity whereby wildlife is hunted with a rifle, a bow or a similar weapon, primarily for horns (measured according to Rowland Ward and Safari Club 
International) and skins, which are subsequently displayed as trophies (Saayman, Van der Merwe, Rossouw \& Oberholzer, 2009:vii).

The combined contribution by trophy and biltong hunting to the South African economy for the 2009 and 2010 season was close to R6 billion (Van der Merwe, Scholtz \& Saayman, 2011). Most of South Africa's hunting takes place in five of the nine provinces: the North West, the Eastern Cape, Limpopo, the Northern Cape and the Free State, the last three being the most popular (Van der Merwe et al., 2011; Warren, 2011). South Africa has some of the best hunting areas in the world, yet little is known about their economic impact. The enormous value to the South African economy of hunting in these three provinces was part of the rationale for determining the economic impact of hunting in selected South African provinces.

2

\section{Research question}

The research issue addressed in this study is that of analysing the economic impact of hunting on the regional economies of three of South Africa's provinces (Limpopo, the Northern Cape and the Free State provinces), where hunting is most popular.

\section{3}

\section{Literature review}

Ritchie and Goeldner (1994) define 'economic impact' as the net economic change in a host community resulting from tourist spending (in this case, by hunters) in a given area. Saayman (2000) maintains that the magnitude of the economic impact of tourism depends on four important factors: the total number of tourists (in this case, the number of hunters), the duration of their stay, average spending by tourists (hunters) and the circulation of tourism expenditure throughout the area or province (see Figure 1).

The literature contains several studies on the economic impact of hunting tourism (Noss, 1997) on the economic impact of communal net hunting among the BaAka of the Central African Republic. For example, studies by Burger, Miller and Southwick (1999) on the economic impact of northern bobwhite hunting in the south eastern United States; the International Association of Fish and Wildlife Agencies (IAFWA 2002) on the economic impact of hunting in America; Baldus and Caulwell (2004) on the economic impact of hunting tourism in Tanzania; Lindsey, Roulet and Romanach (2007) on the economic and conservation significance of trophy hunting in sub-Saharan Africa; BBC Research and Consulting (2008), who published a report for the Colorado Division of Wildlife on the economic impact of hunting, fishing and wildlife watching in Colorado; and Barnes, Nhuleipo, Baker, Muteyauli and Shigwedha (2009) on wildlife resource accounts for Namibia.

Similar studies have been conducted in South Africa: Van der Merwe and Saayman (2005) and Scholtz, Van der Merwe and Saayman (2010) on the profile and economic impact of biltong hunting in South Africa; Van der Merwe, Saayman and Krugell (2007), who identify the determinants of biltong hunters' spending; Saayman, van der Merwe and Rossouw (2011a) on the economic impact of hunting in the Northern Cape Province; and Van der Merwe et al. (2011) on the effect of biltong hunting on the South African economy. However, few studies, either international or South African, have compared the economic impact of hunting on different provinces or regions. This study will therefore address a lacuna in the knowledge of this topic from a geographical point of view.

\subsection{The hunting value chain}

Figure 1 illustrates the value chain responsible for the economic impact of hunting, showing the activities involved and where transactions between the various role players take place.

The first step is to provide information (marketing of the game farm), which is usually done by the provincial tourism board, a municipality or the game farm owners themselves. Once the booking is established, preparations for the hunting trip start. These involve obtaining hunting permits, purchasing ammunition and equipment and making sure the vehicle to be used for the hunting trip is in a good condition. Then, the hunter has to arrange transport to get to the game farm. Once there, the hunter receives information about what to do and how to do it (hunting activities), the variety of game (species) available, and any 
other activities the farm offers. After the hunt, the final transactions concern trophies, meat processing, photographs and videos.

The development of the tourism industry, of which hunting constitutes a major part, is also part of the South African Government's mandate to improve the economy's performance and jobcreating capacity. At the national level, two policies outline the goals set by government, which are contained in the White Paper of 1997 on Tourism and an older policy, the Accelerated and Shared Growth Initiative for South Africa (AsgiSA). The latter is relevant here, as it places heavy emphasis on regional development and on the role of tourism in developing provinces or regions (AsgiSA, 2005). This means that government will provide financial and regulatory support to promote businesses like hunting in these high-growth sectors.

Higher spending and demand by hunters will lead to an increase in business activities in a province or area, which, in turn, will create more employment and income for members of a community or a specific province. A greater demand by hunters means more services and products will be supplied by farmers and other businesses, which in turn will lead to improved infrastructure, including water, electricity, roads, shops and transport (Saayman \& Saayman, 2010:1040).

Figure 1

Hunting value chain

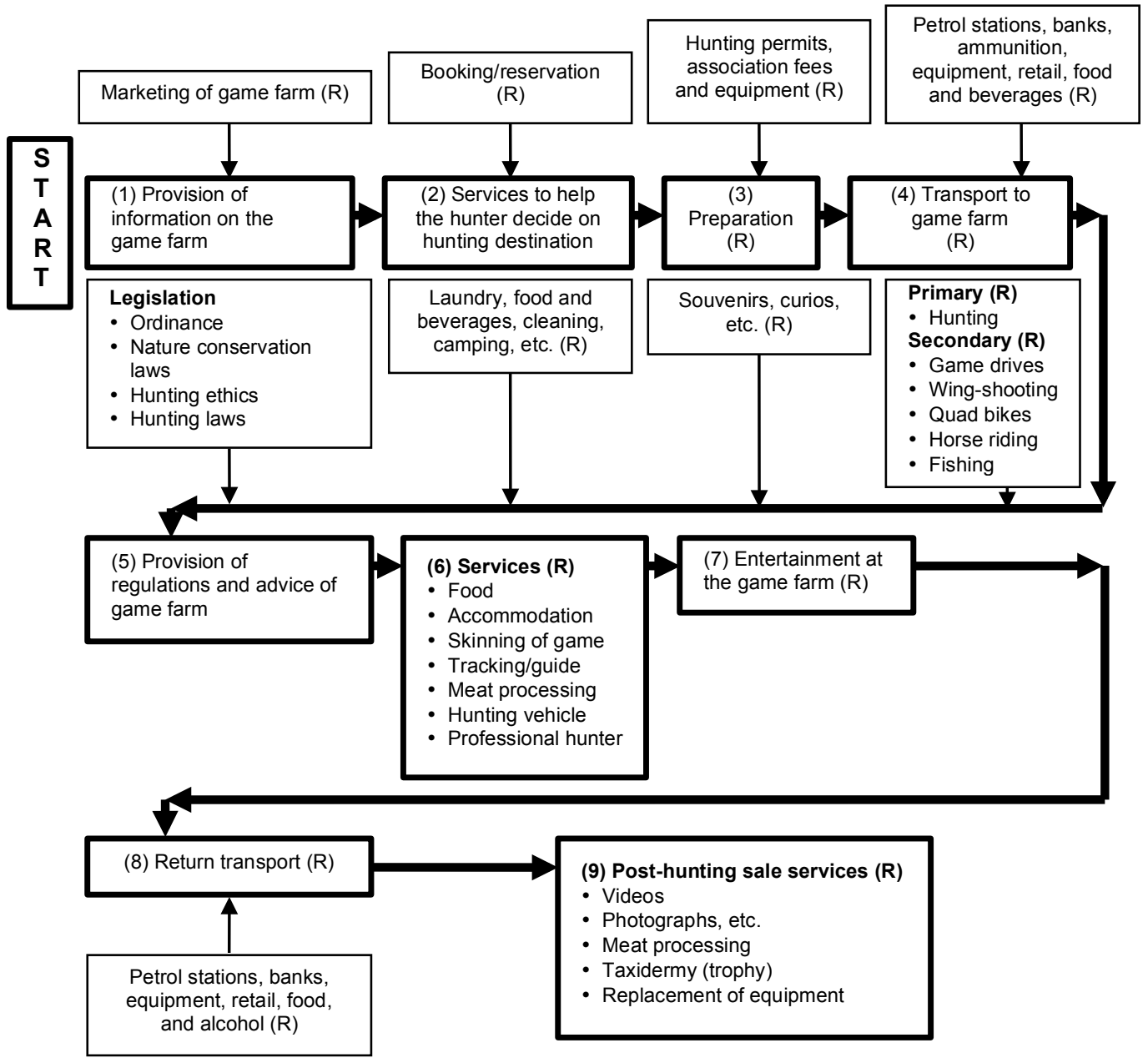

(Adapted from Saayman, Van der Merwe, Rossouw \& Oberholzer, 2011b:11)

Note: The exchange of money is indicated with a $R$ symbol. 


\subsection{Study areas (regions)}

The data for this case study came from South Africa's top three hunting provinces: Limpopo, the Northern Cape and the Free State (see Figure 2). These are described in detail below.

Figure 2

Provinces of South Africa

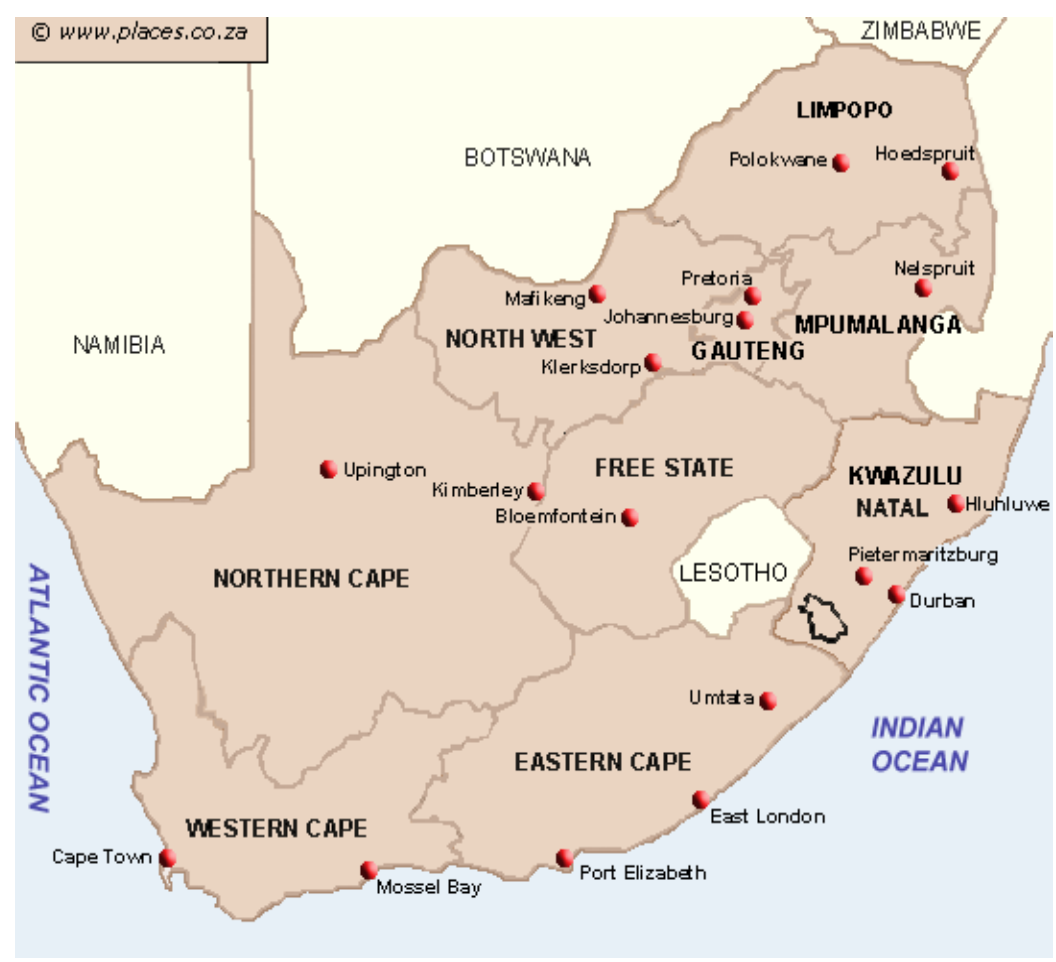

Source: SA Places (2012)

\subsubsection{Limpopo Province}

The Limpopo Province covers a surface area of $125,755 \mathrm{~km}^{2}$, and its share of the total population of South Africa is 10.4\% (5.4 million) (South African Yearbook, 2011, Statistics South Africa, 2012). Its capital, Polokwane, has a population of 130,028 (Statistics South Africa, 2012). The province has an unemployment rate of $35.6 \%$ (Labour Force Survey, 2006c). This is South Africa's northernmost province, bordered by Mozambique, Zimbabwe and Botswana. Fifty percent of South Africa's 9,000 game farms are situated in this province (Eloff, 2002) and about $80 \%$ of the country's hunting takes place here. The province is also rich in minerals, such as coal and iron ore. Limpopo produce contributes $43 \%$ of the R2 billion annual turnover of the Johannesburg
Fresh Produce market. Mining operations, the primary driver of economic activity in the province, contribute $20 \%$ to the province's GDP, while Limpopo's economy contributes $6.7 \%$ to the national GDP.

\subsubsection{Northern Cape Province}

The Northern Cape covers the largest surface area of South Africa's nine provinces $(372,889$ $\mathrm{km}^{2}$ ), taking up almost a third of the country's total land surface. At the same time, it has the smallest population, $2.2 \%$ (1.1 million of the country's total) (South African Yearbook, 2011; Statistics South Africa, 2012). Its capital, Kimberley, has a population of 96,000 (Statistics South Africa, 2012), with an unemployment rate of 23.5\% (Labour Force Survey, 2006b). The province lies south of its most valuable 
asset, the Orange River, which plays an important role in a healthy agricultural industry. The Northern Cape borders two neighbouring countries in the north, Namibia and Botswana (South African Yearbook, 2011:13). The province is famous for its San rock art, its mineral resources (diamonds, iron ore and copper), $4 \times 4$ safaris, game farming, varying topographies and several national parks. Agriculture is an important sector of the province's economy, contributing $8 \%$ of the provincial GDP, as well as being crucial to its overall economic planning. The largest economic contributor to the provincial GDP is mining (30\%), which plays a very important role (Northern Cape Businesses, 2011).

\subsubsection{Free State Province}

The Free State covers a surface area of $129,825 \mathrm{~km}^{2}$. Its share of the total population is 5.3\% (2.7 million) (South African Yearbook, 2011:2; Statistics South Africa, 2012). Its capital, Bloemfontein, has a population of 256 185 , with an unemployment rate of $28.3 \%$ (Labour Force Survey, 2006a). This province lies in the heart of South Africa, with Lesotho on its eastern border. Its economy rests on three core industries, mining, manufacturing and agriculture. With $90 \%$ of its surface under cultivation, the province produces about $40 \%$ of South Africa's maize crop. Agriculture contributes approximately $7 \%$ to the provincial GDP. The Free State generates 14\% of South Africa's agricultural GDP from the $14.5 \%$ of the country's commercial farming. It contributes $14.1 \%$ to the country's national mining production, and is the world's fifth-largest gold producer (Free State Business, 2009).

\section{4 \\ Research design}

The discussion of the research method presents three categories: surveys, expenditure data, and economic impact methodology.

\subsection{Surveys}

The study used three data sets, consisting of secondary and primary data. The first was derived from a South African quantitative survey of biltong hunters (secondary data), conducted via an online interactive question- naire hosted on Pot-Shot, the weekly electronic newsletter of the magazine SA Hunters, from October 2009 to January 2010. 344 (n) completed questionnaires were returned and used in the statistical analysis. The questionnaire was structured in three sections: Section A collected demographic details (marital status, age and province of origin); Section B investigated spending behaviour and motivational factors (the number of persons paid for, the number of visits to the game farm, the length of stay and the amount spent); Section C required more detailed information on the consumers' general behaviour (such as the magazines and newspapers and hunting techniques preferred). This paper refers only to the data from Sections A and B. Mulder (2011) and Radder (2005) had previously used the questionnaire in similar research.

The second data set was derived from interviews with game farm owners in Limpopo and the Free State in May and June 2010 and in the Northern Cape in September 2009 to December 2009 (primary data). The questionnaire, previously used in similar research, was designed by the Institute for Tourism and Leisure Studies, North West University (Saayman et al., 2009). The Wildlife Ranching South Africa (WRSA) database was used for all three provinces. This organization has a member base of $797(\mathrm{~N}=797)$ product owners for Limpopo, $502(\mathrm{~N}=502)$ for the Northern Cape and $292(\mathrm{~N}=292)$ for the Free State. From this database, a probability sample of respondents was drawn for each province: $206(n=206)$ for Limpopo, $110(n=110)$ for the Northern Cape and $104(n=104)$ for the Free State. These respondents were interviewed telephonically in the evenings between 18:00 and 20:00, when they were most likely to be accessible.

\subsection{Expenditure data}

The third data set, representing trophy hunting participation and expenditure data for 2007 , was obtained from the Professional Hunters Association of South Africa (PHASA) for the three provinces (secondary data) (Lindsey et al., 2007).

\subsubsection{Expenditure data: Limpopo}

In 2010, hunters spent an estimated total of R1.5 billion on licences (hunting licences, 
hunting permits), travel, supplies and services directly connected with hunting in Limpopo. Of the total spending by all hunters, biltong hunters spent an estimated $94 \%$ and trophy hunters only $6 \%$ (see Table 1 ). Spending on game/species accounted for $45 \%$ of total expenditure, accommodation and food for $22 \%$, new equipment for $10 \%$, fuel and transport for $9 \%$ and meat processing services for $5 \%$. All other expenditures accounted for approximately $9 \%$ of the total expenditure for 2010. Biltong hunters contributed an estimated R1.4 billion, and trophy hunters an estimated R88.2 million to the Limpopo economy in 2010.

\subsubsection{Expenditure data: Free State}

In 2010, hunters spent an estimated R665.5 million on licences (hunting licences, hunting permits), travel, supplies and services directly connected with hunting in the Free State (see Table 1). Of the total spending by hunters, biltong hunters spent an estimated $97 \%$ but trophy hunters only $3 \%$. Spending on game/ species accounted for $46 \%$ of the total expenditure, accommodation and food for $21 \%$, new equipment for $12 \%$, fuel/transportation for $9 \%$ and meat processing services for $7 \%$. All other expenditures accounted for approximately $5 \%$ of the total expenditure for 2010. In 2010, biltong hunters contributed an estimated R647.3 million and trophy hunters an estimated R18.2 million to the Free State economy.

\subsubsection{Expenditure data: Northern Cape}

Hunters spent an estimated R696 million on licences (hunting licences, hunting permits), travel, supplies and services directly connected with hunting in the Northern Cape. Of the total spending by hunters, biltong hunters spent an estimated $95 \%$ and trophy hunters only 5\% (see Table 1). Food and accommodation accounted for approximately $16 \%$ of the total expenditure, new equipment $8 \%$, fuel/ transportation $8 \%$ and meat processing services $6 \%$. Spending on game/species accounted for $56 \%$. All other expenditure accounted for approximately $8 \%$ of the total expenditure. Biltong hunters contributed an estimated R661.7 million and trophy hunters an estimated R34.3 million to the Northern Cape economy.

Table 1

Expenditure directly related to hunting in 2010 (including game; ZAR Million)

\begin{tabular}{|c|c|c|c|c|}
\hline Province & Category & Trophy hunters & Biltong hunters & Total hunters \\
\hline $\begin{array}{l}\text { Limpopo } \\
\text { Northern Cape } \\
\text { Free State }\end{array}$ & Accommodation & $\begin{array}{r}22.6 \\
3.3 \\
4.1\end{array}$ & $\begin{array}{r}162.3 \\
59.0 \\
72.7\end{array}$ & $\begin{array}{r}184.9 \\
62.3 \\
76.9\end{array}$ \\
\hline $\begin{array}{l}\text { Limpopo } \\
\text { Northern Cape } \\
\text { Free State }\end{array}$ & Fuel & $\begin{array}{l}0.0 \\
1.8 \\
0.0\end{array}$ & $\begin{array}{r}131.1 \\
53.1 \\
58.8\end{array}$ & $\begin{array}{r}131.1 \\
54.9 \\
58.8\end{array}$ \\
\hline $\begin{array}{l}\text { Limpopo } \\
\text { Northern Cape } \\
\text { Free State }\end{array}$ & Food & $\begin{array}{l}9.7 \\
2.0 \\
1.8\end{array}$ & $\begin{array}{l}85.1 \\
32.1 \\
38.1\end{array}$ & $\begin{array}{l}94.8 \\
34.1 \\
39.9\end{array}$ \\
\hline $\begin{array}{l}\text { Limpopo } \\
\text { Northern Cape } \\
\text { Free State }\end{array}$ & Meat processing & $\begin{array}{l}0.0 \\
1.3 \\
0.0 \\
\end{array}$ & $\begin{array}{l}69.8 \\
27.9 \\
31.3 \\
\end{array}$ & $\begin{array}{l}69.8 \\
29.2 \\
31.3 \\
\end{array}$ \\
\hline $\begin{array}{l}\text { Limpopo } \\
\text { Northern Cape } \\
\text { Free State }\end{array}$ & Ammunition & $\begin{array}{r}3.2 \\
53.5 \\
0.6\end{array}$ & $\begin{array}{l}74.0 \\
23.2 \\
33.2\end{array}$ & $\begin{array}{l}77.3 \\
23.7 \\
33.8\end{array}$ \\
\hline $\begin{array}{l}\text { Limpopo } \\
\text { Northern Cape } \\
\text { Free State }\end{array}$ & Gear & $\begin{array}{l}3.2 \\
1.1 \\
0.6\end{array}$ & $\begin{array}{l}40.6 \\
19.8 \\
18.2 \\
\end{array}$ & $\begin{array}{l}43.9 \\
20.9 \\
18.8 \\
\end{array}$ \\
\hline $\begin{array}{l}\text { Limpopo } \\
\text { Northern Cape } \\
\text { Free State }\end{array}$ & Daily fees & $\begin{array}{l}0.0 \\
1.2 \\
0.0\end{array}$ & $\begin{array}{l}46.8 \\
16.7 \\
21.0 \\
\end{array}$ & $\begin{array}{l}46.8 \\
17.9 \\
21.0 \\
\end{array}$ \\
\hline $\begin{array}{l}\text { Limpopo } \\
\text { Northern Cape } \\
\text { Free State }\end{array}$ & Beverages & $\begin{array}{l}0.0 \\
0.7 \\
0.0\end{array}$ & $\begin{array}{l}48.6 \\
17.5 \\
21.8 \\
\end{array}$ & $\begin{array}{l}48.6 \\
18.2 \\
21.8 \\
\end{array}$ \\
\hline $\begin{array}{l}\text { Limpopo } \\
\text { Northern Cape } \\
\text { Free State }\end{array}$ & Butchery facilities & $\begin{array}{r}0.0 \\
33.4 \\
0.0\end{array}$ & $\begin{array}{l}34.0 \\
13.1 \\
15.2\end{array}$ & $\begin{array}{l}34.0 \\
13.4 \\
15.2\end{array}$ \\
\hline
\end{tabular}




\begin{tabular}{|c|c|c|c|c|}
\hline Province & Category & Trophy hunters & Biltong hunters & Total hunters \\
\hline $\begin{array}{l}\text { Limpopo } \\
\text { Northern Cape } \\
\text { Free State }\end{array}$ & Clothes & $\begin{array}{l}3.2 \\
0.3 \\
0.6\end{array}$ & $\begin{array}{l}31.0 \\
10.8 \\
13.9\end{array}$ & $\begin{array}{r}34.2 \\
11.0 \\
14.5\end{array}$ \\
\hline $\begin{array}{l}\text { Limpopo } \\
\text { Northern Cape } \\
\text { Free State }\end{array}$ & Toiletries & $\begin{array}{l}0.6 \\
0.1 \\
0.1\end{array}$ & $\begin{array}{r}13.2 \\
3.4 \\
5.9\end{array}$ & $\begin{array}{r}13.8 \\
3.5 \\
6.0\end{array}$ \\
\hline $\begin{array}{l}\text { Limpopo } \\
\text { Northern Cape } \\
\text { Free State }\end{array}$ & Medicine & $\begin{array}{l}0.6 \\
0.1 \\
0.1\end{array}$ & $\begin{array}{l}8.9 \\
3.3 \\
4.0 \\
\end{array}$ & $\begin{array}{l}9.6 \\
3.4 \\
4.1 \\
\end{array}$ \\
\hline $\begin{array}{l}\text { Limpopo } \\
\text { Northern Cape } \\
\text { Free State }\end{array}$ & Tobacco & $\begin{array}{l}0.0 \\
0.2 \\
0.0\end{array}$ & $\begin{array}{l}4.6 \\
1.1 \\
2.0\end{array}$ & $\begin{array}{l}4.6 \\
1.3 \\
2.0\end{array}$ \\
\hline $\begin{array}{l}\text { Limpopo } \\
\text { Northern Cape } \\
\text { Free State }\end{array}$ & Transport & $\begin{array}{r}12.9 \\
0.0 \\
2.4 \\
\end{array}$ & $\begin{array}{l}0.0 \\
0.0 \\
0.0\end{array}$ & $\begin{array}{r}12.9 \\
0.0 \\
2.4 \\
\end{array}$ \\
\hline $\begin{array}{l}\text { Limpopo } \\
\text { Northern Cape } \\
\text { Free State }\end{array}$ & Trophy handling fees & $\begin{array}{l}1.9 \\
0.0 \\
0.4 \\
\end{array}$ & $\begin{array}{l}0.0 \\
0.0 \\
0.0\end{array}$ & $\begin{array}{l}1.9 \\
0.0 \\
0.4\end{array}$ \\
\hline $\begin{array}{l}\text { Limpopo } \\
\text { Northern Cape } \\
\text { Free State }\end{array}$ & Other & $\begin{array}{l}6.5 \\
0.4 \\
1.2\end{array}$ & $\begin{array}{l}28.9 \\
13.3 \\
13.0\end{array}$ & $\begin{array}{l}35.4 \\
13.7 \\
14.1\end{array}$ \\
\hline $\begin{array}{l}\text { Limpopo } \\
\text { Northern Cape } \\
\text { Free State }\end{array}$ & Game/Species & $\begin{array}{r}23.6 \\
20.9 \\
6.4 \\
\end{array}$ & $\begin{array}{l}670.8 \\
367.6 \\
298.3 \\
\end{array}$ & $\begin{array}{l}694.4 \\
388.5 \\
304.7 \\
\end{array}$ \\
\hline $\begin{array}{l}\text { Limpopo } \\
\text { Northern Cape } \\
\text { Free State }\end{array}$ & Total & $\begin{array}{l}88.2 \\
20.9 \\
18.2\end{array}$ & $\begin{array}{r}1449.5 \\
661.7 \\
647.3\end{array}$ & $\begin{array}{r}1537.8 \\
696.0 \\
665.5\end{array}$ \\
\hline
\end{tabular}

Source: Data from the survey

\subsubsection{Measuring economic impact}

Wagner (1997) stated that the Input-Output (IO) and Social Accounting Matrix (SAM) models are among the most popular impact methods used, with the measurement of backward and forward linkages becoming a standard in these types of analyses. Taljaard (2007), went on to suggest that, when developments in the analysis of transactions within an economy are expanded to include the entire economy and its linkages, the original I-O transaction matrix can be set in the wider accounting framework of a SAM. Thus, SAM models can be viewed as a more comprehensive approach to measuring the effect of hunting-related expenditure on the selected economic and socio-economic aggregates.

A SAM model can therefore be used to capture the economy-wide effects of an exogenous shock. For example, hunters spend money on a variety of goods and services for trip- and equipment-related purchases (see Figure 1). However, these direct expenditures are only part of the economic impact of hunting, as they also have economy-wide effects. The resulting impact on the economy in excess of direct expenditures is known as a multiplier effect. For example, an individual may purchase ammunition to use for hunting (see Figure 1). Part of the purchase price will stay with the local retailer. The local retailer in turn pays a wholesaler, who in turn pays the manufacturer of the ammunition. The manufacturer then spends a portion of this income to pay businesses supplying the manufacturer. Each rand of local retail expenditure can affect a variety of businesses. In this way, expenditure associated with hunting can spread through the economy, affecting economic activity, employment and household income.

In the present study, the authors used three different SAMs. These were compiled by Conningarth Economists (2006) and are available from the Development Bank of Southern Africa (DBSA). The SAMs (based on 2006 prices) used in these analyses distinguish 35 sectors for the Northern Cape, 36 for the Free State, 46 for Limpopo, and across all three SAMs, 12 household types and 4 ethnic groups. The three provinces differ significantly in economic make-up, largely because of the types of activities, endowment of natural resources and other factors of production specific to each. The Northern Cape, for instance, has mining, trade and agriculture as its three top performing sectors in terms of 
value added; the Free State has chemicals and chemical products, community, social and personal services, and trade; Limpopo has platinum mining, trade and real estate.

The analysis in this study is based on two models. The first is a standard I-O Leontief model, for which input coefficients and Leontief multipliers $\left(M^{L}\right)$ were calculated (Hajnovicova \& Lapisakova, 2002):

$$
M^{L}=(E-A)^{-1} \text {, }
$$

where $A$ is a matrix of input (technical) coefficients.

The second extends the linear Leontief model to a SAM framework by partitioning the accounts into endogenous and exogenous accounts and assuming that the column coefficients of the endogenous accounts are all constant (Pyatt \& Round, 1985).

Multipliers calculated from the SAM are the simple indicators comprising the important information about the structure of the three provincial economies. They are calculated from the matrix of expenditures shares (general technical coefficients) after excluding the exogenous accounts. The computed multipliers will be sensitive to the choice of exogenous accounts and express the sensitivity of the endogenous accounts to changes in demand for exogenous accounts (Hajnovicova \& Lapisakova, 2002). SAM multipliers $\left(M^{S}\right)$ are calculated as:

$$
M^{S}=(E-M)^{-1} \text {, }
$$

where $M$ is the matrix of expenditures shares of endogenous accounts.

Comparing the multipliers calculated from the I-O and SAM models introduces new aspects into the economic analysis. The SAM multipliers are much larger than the corresponding I-O multipliers. Because value-added is a leakage, only intermediate demand serves as a multiplier in the I-O analysis. In contrast, in the SAM approach, value-added and incomes generate demand linkages. SAM multipliers capture the different multiplier effects of exogenous accounts on productive activities, factors and institutions. On the basis of the partition of the endogenous section of the SAM into three categories of accounts (activities/ commodities, factors and institutions), the matrix of multipliers can be decomposed into four components: initial injection, transfer effects, open-loop effects and closed-loop effects. Many versions of this decomposition have been used previously (Hajnovicova \& Lapisakova, 2002).

Pyatt and Round (1985) used a decomposition of multipliers when analysing the productive sphere of the economy The matrix $M^{S}$ which is reduced to the Leontief multiplier matrix $M^{L}$ corresponds only to the production accounts. To perform the impact analysis, the $M^{S}$ matrix is truncated to conform to the dimension of the matrix $M^{L}$.

The differences between the multiplier matrices $M^{S}$ and $M^{L}$ measure the induced effects due to the added endogeneity, while the direct and indirect effects are measured by $M^{L}$. Matrix $M^{S}$ can be decomposed into three components:

$\left(M^{S}-M^{L}\right)$, which measures induced effects

$(E+A)$, which measures direct effects

$\left(M^{L}-E-A\right)$, which measures indirect effects,

\section{where}

$$
M^{S}=\left(M^{S}-M^{L}\right)+(E+A)+\left(M^{L}-E-A\right) .
$$

The justification for using economic multipliers, calculated from a SAM as a method for impact analysis rests on the appropriate interpretation of the results. The key assumption of fixed relative prices and a perfectly elastic supply of economic multipliers therefore has to be considered when interpreting the results from the multiplier analysis. Moreover, the data reflects the structure of the provincial economies during 2006, that is, the multipliers are calculated for 2006 constant Rands.

While bearing these assumptions in mind, multiplier analysis can expose the interaction between and across production activities, factors of production and institutions. Multiplier analysis will therefore not only reflect the direct contribution towards set economic and socioeconomic parameters, but will also inform on the indirect and induced contributions.

Finally, the benefit of multiplier analysis is that it captures the inter-linkages and feedback effects between sectors in an economy, thus giving an idea of the relative strength and flow-through effects of an exogenous shock. Hence, even though the study was conducted during the economic boom, and despite the current economic downturn, the results are still relevant. This is because the focus is on the relative impact of the increased expenditure 
resulting from the hunting activity, rather than the absolute effects.

\section{5}

\section{Results}

Using the figures in Table 1 and the latest SAMs for the Limpopo, the Free State and the Northern Cape provinces (Conningarth Economists, 2006), it was possible to determine the estimated share of expenditure in the study areas (using the multiplier concept). Table 1 shows the real spending by both groups of hunters (biltong and trophy) on goods and services in the three provinces.

The information included in the SAMs enabled the identification of the impacts of hunting on household groups, components of the labour force and income inequality (Blake, Arbache, Sinclair \& Teles, 2008). The figures in Table 1 for spending by hunters, recorded in surveys of biltong and trophy hunters, were used to estimate the share of total expenditure in the study areas resulting from hunting. Considering these figures, it can be understood that the manufacturing and service industries catering directly for hunters experience the greatest direct economic impact from huntingrelated activities. Conversely, the industries that supply these activities only indirectly receive less benefit (subject also to the 'backward linkages' in the regional economy).

\subsection{Secondary and total economic impact}

The biltong and trophy hunters' spending was linked to the associated increase in production, income and jobs in the provincial economies using economic multipliers from SAMs for Limpopo, the Free State and the Northern Cape. The SAM multiplier approach uses distinct multipliers for each expenditure-related sector. The multipliers convert expenditure into the associated increase in production, jobs and income and estimate secondary effects as spending circulates through the provincial economies. To show this for the biltong and trophy hunter spending, it was necessary to 'correct' the direct impact (for example, expenditure figures in Table 1) by using the multiplier approach. These results, based on the 'corrected' spending by the two types of hunters (refer to column 2 in Tables 2 and 3), are contained in the next two sections.

\subsection{Trophy hunters}

The quantification of the direct, indirect and induced impact of spending by trophy hunters in the three provinces in 2010 is summarised in Table 2. As this expenditure comes in part from trophy hunters from other provinces and abroad buying goods and services in the region, it represents an inflow of money into the region, mobilising economic activity and generating employment and additional revenue for the province. 'Production' refers to the total turnover generated by each sector in the regional economy. As such, production comprises two components: demand for intermediate inputs (resources) by an activity (domestically produced and imported goods and services); and total value-added generated by an activity (Conningarth Economists, 2006). Table 2 shows the effects on production (using the production multipliers) of expenditure resulting from trophy hunting in 2010.

From Table 2, it is clear that the largest direct impacts for Limpopo were on trade and accommodation (29\%), transport and communication $(21 \%)$, financial and business services (17\%) and manufacturing (13\%). For the Northern Cape, they were on agriculture $(60 \%)$, manufacturing (15\%), trade and accommodation (9\%) and community/general services (7\%), while for the Free State, the impacts were on manufacturing $(38 \%)$, trade and accommodation $(20 \%)$ and transport and communication (12\%).

In Limpopo, through backward linkages, large indirect and induced impacts were also experienced in the manufacturing sector, reflecting an indirect impact of R6.7 million and an induced impact of R2.9 million. Note that, if the direct effect in the manufacturing sector is ignored, it is found that $46 \%$ of the total increase in production was the result of backward linkages, with direct expenditure representing 54\%. In the Northern Cape, through backward linkages, large indirect and induced impacts were also experienced in the agricultural sector, reflecting an indirect impact of R11.6 million and an induced impact of R6.4 million. If the direct effect in the financial and business services sectors is 
ignored, $53 \%$ of the total increase in production was the result of backward linkages, with direct foreign expenditure representing only $47 \%$. In the Free State, through backward linkages, large indirect and induced impacts were also experienced in the manufacturing sector, reflecting an indirect impact of R6.1 million and an induced impact of R1.8 million.
If the direct effect in the manufacturing sector is ignored, $56 \%$ of the total increase in production was the result of backward linkages, with direct expenditure representing only $44 \%$. For all three provinces, a more detailed (disaggregated) analysis of the various sectors would be useful, but unfortunately there was insufficient expenditure data to permit this.

Table 2

Trophy hunters' impact through production multipliers (ZAR Million, 2006 prices)

\begin{tabular}{|c|c|c|c|c|c|}
\hline Sector & Direct impact ${ }^{1}$ & Indirect impact $^{2}$ & Induced impact $^{3}$ & Total impact ${ }^{4}$ & $\%$ (total) \\
\hline $\begin{array}{l}\text { Agriculture } \\
\text { Limpopo } \\
\text { Northern Cape } \\
\text { Free State }\end{array}$ & $\begin{array}{r}7.54 \\
20.93 \\
2.09\end{array}$ & $\begin{array}{r}2.99 \\
11.57 \\
1.49\end{array}$ & $\begin{array}{l}2.28 \\
6.42 \\
0.61\end{array}$ & $\begin{array}{r}12.81 \\
38.92 \\
4.18\end{array}$ & $\begin{array}{r}8.2 \% \\
59.9 \% \\
11.3 \%\end{array}$ \\
\hline $\begin{array}{l}\text { Mining } \\
\text { Limpopo } \\
\text { Northern Cape } \\
\text { Free State }\end{array}$ & $\begin{array}{l}1.47 \\
0.00 \\
0.20\end{array}$ & $\begin{array}{l}0.42 \\
0.00 \\
0.07\end{array}$ & $\begin{array}{l}0.59 \\
0.00 \\
0.08\end{array}$ & $\begin{array}{l}2.48 \\
0.00 \\
0.34\end{array}$ & $\begin{array}{l}1.6 \% \\
0 \\
0.9 \%\end{array}$ \\
\hline $\begin{array}{l}\text { Manufacturing } \\
\text { Limpopo } \\
\text { Northern Cape } \\
\text { Free State }\end{array}$ & $\begin{array}{r}11.22 \\
4.98 \\
6.15\end{array}$ & $\begin{array}{l}6.71 \\
3.75 \\
6.14\end{array}$ & $\begin{array}{l}2.91 \\
1.22 \\
1.82\end{array}$ & $\begin{array}{r}20.84 \\
9.96 \\
14.10\end{array}$ & $\begin{array}{l}13.4 \% \\
15.3 \% \\
38.0 \%\end{array}$ \\
\hline $\begin{array}{l}\text { Electricity \& water } \\
\text { Limpopo } \\
\text { Northern Cape } \\
\text { Free State }\end{array}$ & $\begin{array}{l}2.63 \\
0.00 \\
0.28\end{array}$ & $\begin{array}{l}1.34 \\
0.00 \\
0.15\end{array}$ & $\begin{array}{l}1.01 \\
0.00 \\
0.10\end{array}$ & $\begin{array}{l}4.98 \\
0.00 \\
0.53\end{array}$ & $\begin{array}{l}3.2 \% \\
0 \\
1.4 \%\end{array}$ \\
\hline $\begin{array}{l}\text { Construction } \\
\text { Limpopo } \\
\text { Northern Cape } \\
\text { Free State }\end{array}$ & $\begin{array}{l}1.00 \\
0.00 \\
0.12\end{array}$ & $\begin{array}{l}0.62 \\
0.00 \\
0.09\end{array}$ & $\begin{array}{l}0.26 \\
0.00 \\
0.04\end{array}$ & $\begin{array}{l}1.89 \\
0.00 \\
0.26\end{array}$ & $\begin{array}{l}1.2 \% \\
0 \\
0.7 \%\end{array}$ \\
\hline $\begin{array}{l}\text { Trade \& accommodation } \\
\text { Limpopo } \\
\text { Northern Cape } \\
\text { Free State }\end{array}$ & $\begin{array}{r}23.99 \\
3.30 \\
3.56\end{array}$ & $\begin{array}{r}12.92 \\
1.96 \\
2.35\end{array}$ & $\begin{array}{l}8.26 \\
0.85 \\
1.38\end{array}$ & $\begin{array}{r}45.17 \\
6.11 \\
7.30\end{array}$ & $\begin{array}{r}29.0 \% \\
9.4 \% \\
19.7 \% \\
\end{array}$ \\
\hline $\begin{array}{l}\text { Transport \& communication } \\
\text { Limpopo } \\
\text { Northern Cape } \\
\text { Free State }\end{array}$ & $\begin{array}{r}18.69 \\
1.75 \\
2.18\end{array}$ & $\begin{array}{l}7.81 \\
1.00 \\
1.37\end{array}$ & $\begin{array}{l}5.99 \\
0.54 \\
0.76\end{array}$ & $\begin{array}{r}32.49 \\
3.28 \\
4.31\end{array}$ & $\begin{array}{r}20.9 \% \\
5.0 \% \\
11.6 \%\end{array}$ \\
\hline $\begin{array}{l}\text { Financial \& business } \\
\text { services } \\
\text { Limpopo } \\
\text { Northern Cape } \\
\text { Free State }\end{array}$ & $\begin{array}{r}14.36 \\
1.20 \\
2.18\end{array}$ & $\begin{array}{l}5.92 \\
0.92 \\
1.37 \\
\end{array}$ & $\begin{array}{l}5.63 \\
0.43 \\
0.76 \\
\end{array}$ & $\begin{array}{l}25.92 \\
2.55 \\
4.312 \\
\end{array}$ & $\begin{array}{r}16.6 \% \\
3.9 \% \\
11.6 \% \\
\end{array}$ \\
\hline $\begin{array}{l}\text { Community services } \\
\text { Limpopo } \\
\text { Northern Cape } \\
\text { Free State }\end{array}$ & $\begin{array}{l}5.57 \\
2.14 \\
1.47\end{array}$ & $\begin{array}{l}1.24 \\
0.98 \\
0.38\end{array}$ & $\begin{array}{l}2.34 \\
1.08 \\
0.60\end{array}$ & $\begin{array}{l}9.15 \\
4.21 \\
2.45\end{array}$ & $\begin{array}{l}5.9 \% \\
6.5 \% \\
6.6 \%\end{array}$ \\
\hline $\begin{array}{l}\text { Total (in ZAR) } \\
\text { Limpopo } \\
\text { Northern Cape } \\
\text { Free State }\end{array}$ & $\begin{array}{l}86.47 \\
34.30 \\
17.90\end{array}$ & $\begin{array}{l}39.98 \\
20.18 \\
13.05\end{array}$ & $\begin{array}{r}29.29 \\
10.55 \\
6.11\end{array}$ & $\begin{array}{r}155.74 \\
65.03 \\
37.07\end{array}$ & $\begin{array}{l}100 \% \\
100 \% \\
100 \%\end{array}$ \\
\hline
\end{tabular}

Source: Authors' own calculations based on multiplier analysis

Notes:

1 Initial expenditures (for example, by day visitors) are generally called the direct costs of an activity and their effects on the

economy are direct effects.

2 Purchases by suppliers (for example, hotel and restaurant owners, charter operators, etc.) of the final goods, and services of materials and supplies to maintain the original purchases, are called indirect effects.

3 Induced effects occur when workers in the sectors stimulated by direct and indirect expenditures spend their additional income on consumer goods and services.

4 The direct plus indirect plus induced effects equal the total effect. 
Any acquisition of goods and services from non-regional suppliers (leakages) was excluded from the analysis and therefore did not exert a significant direct or indirect effect on the regional economy. By excluding this indirect impact, although it is of less significance, a more accurate estimate of the impact of trophy hunting in the region can be presented.

The analysis of the spending by trophy hunters in 2010 allows for two conclusions. The first is that, for Limpopo, the direct effect represents $56 \%$, the indirect effect $26 \%$, and the induced effect $19 \%$ of the total increase in expenditure; for the Northern Cape, these effects are $53 \%, 31 \%$ and $16 \%$ respectively, while for the Free State, the figures are $48 \%$, $35 \%$ and $17 \%$ respectively. The second is that the activity sectors that benefited most from spending by trophy hunters in 2010 were trade and accommodation, transport and communication, financial and business services, and manufacturing for Limpopo; agriculture, manufacturing, and trade and accommodation for the Northern Cape; and manufacturing, trade and accommodation, transport and communication services, and agriculture in the Free State.

The regional spending by trophy hunters in these sectors in 2010 exceeded R155.7 million (Limpopo), R65 million (Northern Cape) and R37.1 million (Free State), representing some $6 \%, 5 \%$ and $3 \%$, respectively, of the total spending by all hunters (including biltong hunters) in the three provinces.

\subsection{Biltong hunters}

To estimate the economic impact of the spending in 2010 by biltong hunters (meaning not only non-residents or foreigners but also those living in Limpopo, the Northern Cape and the Free State and the rest of South Africa), the same approach was used as that for trophy hunters. On the basis of the expenditure figures, it is estimated that the direct impact in the three provinces of the biltong hunters' expenditure amounted to approximately R1.4 billion (Limpopo), R662 million (Northern Cape) and R637 million (Free State), distributed among the nine activity sectors. The sectors that benefited most from spending by biltong hunters per province were trade and accommodation, financial and business services, agriculture, and manufacturing in Limpopo; agriculture, manufacturing, community/general services, trade and accommodation, and, to a lesser extent, transport and communication in the Northern Cape; and manufacturing, trade and accommodation, agriculture, and financial and business services for the Free State.

The quantification of the direct, indirect, and induced impact of this expenditure in the three provinces is summarised in Table 3. The total impact was R2.3 billion for Limpopo, R1.2 billion for the Northern Cape and R1.3 billion for the Free State. Limpopo biltong hunters spent R1 billion more than did those in the Northern Cape and Free State.

Table 3 shows clearly that for Limpopo the largest direct impact was on trade and accommodation $(27,3 \%)$, financial and business services (23.6\%), agriculture (18.1\%), and manufacturing (16.2\%); for the Northern Cape, the largest direct impact was on agriculture (54.8\%, a part of which was expenditure on game/species), and manufacturing (16.7\%); and for the Free State, the largest impact was on manufacturing (46.7\%), trade and accommodation $(15.7 \%)$, agriculture $(12.2 \%)$, and financial and business services (12.1\%).

In Limpopo, through backward linkages, large indirect and induced impacts were also experienced in the agricultural sector, reflecting an indirect impact of R101.1 million and an induced impact of R76.9 million. If the direct effect in the agricultural sector is ignored, $42 \%$ of the total increase in production was the result of backward linkages, with direct expenditure also representing $58 \%$ of the total impact. In summary, the direct effect represented $58 \%$, the indirect effect $24 \%$ and the induced effect $20 \%$ of the total increase in expenditure. In the Northern Cape, through backward linkages, large indirect and induced impacts were also experienced in the community/ general services sector (despite a less significant direct impact), reflecting an indirect impact of R26.6 million and an induced impact of R29.1 million. Again, if the direct effect on the community/general services sector is ignored, $49 \%$ of the total increase in production was as the result of backward linkages, with direct local and foreign expenditure representing $51 \%$ of the total impact. In the Free State, through backward linkages, large indirect and 
induced impacts were also experienced in the agricultural sector, reflecting an indirect impact of R57.2 million and an induced impact of R23.5 million. If the direct effect in the agricultural sector is again ignored, $50 \%$ of the total increase in production was the result of backward linkages, with direct expenditure also representing $50 \%$ of the total impact.

Table 3

Biltong hunters' impact through production multipliers (ZAR Million, 2006 prices)

\begin{tabular}{|c|c|c|c|c|c|}
\hline Sector & Direct impact & Indirect impact & Induced impact & Total impact & $\%$ (total) \\
\hline $\begin{array}{l}\text { Agriculture } \\
\text { Limpopo } \\
\text { Northern Cape } \\
\text { Free State }\end{array}$ & $\begin{array}{r}250.96 \\
367.57 \\
80.18\end{array}$ & $\begin{array}{r}101.09 \\
203.28 \\
57.23\end{array}$ & $\begin{array}{r}76.88 \\
112.85 \\
23.48\end{array}$ & $\begin{array}{l}428.93 \\
683.70 \\
160.89\end{array}$ & $\begin{array}{l}18.1 \% \\
54.8 \% \\
12.2 \%\end{array}$ \\
\hline $\begin{array}{l}\text { Mining } \\
\text { Limpopo } \\
\text { Northern Cape } \\
\text { Free State }\end{array}$ & $\begin{array}{r}21.96 \\
0.00 \\
8.83\end{array}$ & $\begin{array}{l}6.71 \\
0.00 \\
3.09\end{array}$ & $\begin{array}{l}8.82 \\
0.00 \\
3.59\end{array}$ & $\begin{array}{r}37.49 \\
0.00 \\
15.51\end{array}$ & $\begin{array}{l}1.6 \% \\
0.0 \% \\
1.2 \%\end{array}$ \\
\hline $\begin{array}{l}\text { Manufacturing } \\
\text { Limpopo } \\
\text { Northern Cape } \\
\text { Free State }\end{array}$ & $\begin{array}{l}211.75 \\
108.84 \\
271.50\end{array}$ & $\begin{array}{r}112.87 \\
73.56 \\
265.37\end{array}$ & $\begin{array}{l}58.78 \\
25.91 \\
81.17\end{array}$ & $\begin{array}{l}383.40 \\
208.31 \\
618.05\end{array}$ & $\begin{array}{l}16.2 \% \\
16.7 \% \\
46.7 \%\end{array}$ \\
\hline $\begin{array}{l}\text { Electricity \& water } \\
\text { Limpopo } \\
\text { Northern Cape } \\
\text { Free State }\end{array}$ & $\begin{array}{r}35.50 \\
0.00 \\
8.40\end{array}$ & $\begin{array}{r}18.26 \\
0.00 \\
4.71 \\
\end{array}$ & $\begin{array}{r}13.65 \\
0.00 \\
2.94 \\
\end{array}$ & $\begin{array}{r}67.41 \\
0.00 \\
16.05 \\
\end{array}$ & $\begin{array}{l}2.8 \% \\
0.0 \% \\
1.2 \%\end{array}$ \\
\hline $\begin{array}{l}\text { Construction } \\
\text { Limpopo } \\
\text { Northern Cape } \\
\text { Free State }\end{array}$ & $\begin{array}{r}14.47 \\
0.00 \\
4.77 \\
\end{array}$ & $\begin{array}{l}8.99 \\
0.00 \\
3.64 \\
\end{array}$ & $\begin{array}{l}3.73 \\
0.00 \\
1.51\end{array}$ & $\begin{array}{r}27.20 \\
0.00 \\
9.93\end{array}$ & $\begin{array}{l}1.1 \% \\
0.0 \% \\
0.8 \%\end{array}$ \\
\hline $\begin{array}{l}\text { Trade \& accommodation } \\
\text { Limpopo } \\
\text { Northern Cape } \\
\text { Free State }\end{array}$ & $\begin{array}{r}345.75 \\
59.01 \\
102.28\end{array}$ & $\begin{array}{r}177.88 \\
35.01 \\
64.35\end{array}$ & $\begin{array}{r}122.73 \\
15.21 \\
41.32\end{array}$ & $\begin{array}{l}646.37 \\
109.23 \\
207.95\end{array}$ & $\begin{array}{r}27.3 \% \\
8.8 \% \\
15.7 \%\end{array}$ \\
\hline $\begin{array}{l}\text { Transport \& communication } \\
\text { Limpopo } \\
\text { Northern Cape } \\
\text { Free State }\end{array}$ & $\begin{array}{r}121.36 \\
52.07 \\
38.48\end{array}$ & $\begin{array}{l}49.86 \\
29.76 \\
23.67\end{array}$ & $\begin{array}{l}38.94 \\
16.15 \\
13.42\end{array}$ & $\begin{array}{r}210.16 \\
97.97 \\
75.56\end{array}$ & $\begin{array}{l}8.9 \% \\
7.9 \% \\
5.7 \%\end{array}$ \\
\hline $\begin{array}{l}\text { Financial \& business } \\
\text { services } \\
\text { Limpopo } \\
\text { Northern Cape } \\
\text { Free State }\end{array}$ & $\begin{array}{r}325.95 \\
16.71 \\
86.93\end{array}$ & $\begin{array}{l}97.99 \\
12.70 \\
37.93\end{array}$ & $\begin{array}{r}136.62 \\
5.95 \\
35.75\end{array}$ & $\begin{array}{r}560.57 \\
35.36 \\
160.61\end{array}$ & $\begin{array}{r}23.6 \% \\
2.8 \% \\
12.1 \%\end{array}$ \\
\hline $\begin{array}{l}\text { Community services } \\
\text { Limpopo } \\
\text { Northern Cape } \\
\text { Free State }\end{array}$ & $\begin{array}{l}53.32 \\
57.55 \\
35.53\end{array}$ & $\begin{array}{r}1.24 \\
26.56 \\
9.13\end{array}$ & $\begin{array}{r}2.34 \\
29.01 \\
14.39\end{array}$ & $\begin{array}{r}9.15 \\
113.11 \\
59.05\end{array}$ & $\begin{array}{l}0.4 \% \\
9.1 \% \\
4.5 \%\end{array}$ \\
\hline $\begin{array}{l}\text { Total (in ZAR) } \\
\text { Limpopo } \\
\text { Northern Cape } \\
\text { Free State }\end{array}$ & $\begin{array}{r}1381.03 \\
661.74 \\
636.90\end{array}$ & $\begin{array}{l}574.91 \\
380.87 \\
469.11\end{array}$ & $\begin{array}{l}462.50 \\
205.08 \\
217.58\end{array}$ & $\begin{array}{l}2370.69 \\
1247.69 \\
1323.59\end{array}$ & $\begin{array}{l}100 \% \\
100 \% \\
100 \%\end{array}$ \\
\hline
\end{tabular}

Source: Authors' own calculations based on multiplier analysis

\subsection{Overall impact}

The results in the two previous sections allow the estimation of the direct impact on the Limpopo, Free State and Northern Cape economies of spending by trophy and biltong hunters. However, to evaluate the total impact of spending by hunters in the selected regions, it was necessary to 'correct' the direct impact with the multiplier effect. Production multipliers were thus used for each of the activity sectors. Multiplying the direct impact in each activity sector for the specific production multipliers gives the total impact of the hunter spending for each of the provinces' economic sectors (Table 4). The sum of the impacts in each of the sectors gives us, in turn, an estimate of the total impact of hunter spending in the three provinces. 
Table 4

Total impact of hunter spending on regional production per province (ZAR Million)

\begin{tabular}{|c|c|c|c|c|c|}
\hline Sectors & $\begin{array}{l}\text { Spending by } \\
\text { biltong hunters }\end{array}$ & $\begin{array}{c}\text { Spending by } \\
\text { trophy } \\
\text { hunters }\end{array}$ & $\begin{array}{l}\text { Direct impact } \\
\text { of hunters }\end{array}$ & $\begin{array}{l}\text { Production } \\
\text { multipliers }\end{array}$ & $\begin{array}{l}\text { Total impact } \\
\text { (Millions) }\end{array}$ \\
\hline $\begin{array}{l}\text { Agriculture } \\
\text { Limpopo } \\
\text { Northern Cape } \\
\text { Free State }\end{array}$ & $\begin{array}{r}250.96 \\
367.57 \\
80.18\end{array}$ & $\begin{array}{r}7.53 \\
20.92 \\
2.08\end{array}$ & $\begin{array}{r}258.49 \\
388.49 \\
82.26\end{array}$ & $\begin{array}{l}1.650 \\
0.463 \\
2.006\end{array}$ & $\begin{array}{l}441.74 \\
335.28 \\
165.07\end{array}$ \\
\hline $\begin{array}{l}\text { Mining } \\
\text { Limpopo } \\
\text { Northern Cape } \\
\text { Free State }\end{array}$ & $\begin{array}{c}21.95 \\
0.0 \\
8.83\end{array}$ & $\begin{array}{l}1.46 \\
0.0 \\
0.2\end{array}$ & $\begin{array}{l}23.42 \\
0 \\
9.023\end{array}$ & $\begin{array}{l}1.777 \\
0 \\
3.542\end{array}$ & $\begin{array}{c}39.97 \\
0 \\
15.86\end{array}$ \\
\hline $\begin{array}{l}\text { Manufacturing } \\
\text { Limpopo } \\
\text { Northern Cape } \\
\text { Free State }\end{array}$ & $\begin{array}{l}211.74 \\
108.83 \\
271.50\end{array}$ & $\begin{array}{r}11.22 \\
4.98 \\
6.14\end{array}$ & $\begin{array}{l}222.97 \\
113.82 \\
277.65\end{array}$ & $\begin{array}{l}1.594 \\
2.039 \\
3.927\end{array}$ & $\begin{array}{l}404.24 \\
232.08 \\
632.14\end{array}$ \\
\hline $\begin{array}{l}\text { Electricity \& water } \\
\text { Limpopo } \\
\text { Northern Cape } \\
\text { Free State }\end{array}$ & $\begin{array}{c}35.50 \\
0.0 \\
8.39\end{array}$ & $\begin{array}{l}2.62 \\
0.0 \\
0.3\end{array}$ & $\begin{array}{l}38.13 \\
0 \\
8.7\end{array}$ & $\begin{array}{l}1.932 \\
0 \\
3.935\end{array}$ & $\begin{array}{c}72.40 \\
0 \\
16.60\end{array}$ \\
\hline $\begin{array}{l}\text { Construction } \\
\text { Limpopo } \\
\text { Northern Cape } \\
\text { Free State }\end{array}$ & $\begin{array}{c}14.47 \\
0.0 \\
4.77\end{array}$ & $\begin{array}{l}1.00 \\
0 \\
0.1\end{array}$ & $\begin{array}{l}15.48 \\
0 \\
4.89\end{array}$ & $\begin{array}{l}1.879 \\
0 \\
2.081\end{array}$ & $\begin{array}{c}29.08 \\
0 \\
10.18\end{array}$ \\
\hline $\begin{array}{l}\text { Trade \& accommodation } \\
\text { Limpopo } \\
\text { Northern Cape } \\
\text { Free State }\end{array}$ & $\begin{array}{r}345.75 \\
59.01 \\
102.27\end{array}$ & $\begin{array}{r}23.98 \\
3.30 \\
3.56\end{array}$ & $\begin{array}{r}369.74 \\
62.32 \\
105.84\end{array}$ & $\begin{array}{l}1.879 \\
0.800 \\
2.104\end{array}$ & $\begin{array}{r}691.54 \\
49.85 \\
215.25\end{array}$ \\
\hline $\begin{array}{l}\text { Transport \& } \\
\text { communication } \\
\text { Limpopo } \\
\text { Northern Cape } \\
\text { Free State }\end{array}$ & $\begin{array}{r}121.36 \\
52.06 \\
38.47\end{array}$ & $\begin{array}{r}18.69 \\
1.74 \\
2.17\end{array}$ & $\begin{array}{r}140.05 \\
53.81 \\
40.65\end{array}$ & $\begin{array}{l}1.730 \\
0.735 \\
3.913\end{array}$ & $\begin{array}{r}242.66 \\
39.55 \\
79.88\end{array}$ \\
\hline $\begin{array}{l}\text { Financial \& business } \\
\text { services } \\
\text { Limpopo } \\
\text { Northern Cape } \\
\text { Free State }\end{array}$ & $\begin{array}{r}325.95 \\
16.70 \\
86.93\end{array}$ & $\begin{array}{r}14.36 \\
1.20 \\
2.17\end{array}$ & $\begin{array}{r}340.31 \\
17.91 \\
89.11\end{array}$ & $\begin{array}{l}1.762 \\
1.495 \\
3.592\end{array}$ & $\begin{array}{r}586.48 \\
26.78 \\
164.20\end{array}$ \\
\hline $\begin{array}{l}\text { Community services } \\
\text { Limpopo } \\
\text { Northern Cape } \\
\text { Free State }\end{array}$ & $\begin{array}{l}53.31 \\
57.55 \\
35.53\end{array}$ & $\begin{array}{l}5.57 \\
2.14 \\
1.47\end{array}$ & $\begin{array}{l}58.88 \\
59.69 \\
37.00\end{array}$ & $\begin{array}{l}1.322 \\
1.521 \\
2.662\end{array}$ & $\begin{array}{l}96.82 \\
90.79 \\
61.50\end{array}$ \\
\hline $\begin{array}{l}\text { Total (in ZAR) } \\
\text { Limpopo } \\
\text { Northern Cape } \\
\text { Free State }\end{array}$ & $\begin{array}{r}1381.02 \\
661.74 \\
636.90\end{array}$ & $\begin{array}{l}86.47 \\
34.30 \\
17.90\end{array}$ & $\begin{array}{c}1467.49 \\
696.04 \\
654.801\end{array}$ & & $\begin{array}{r}2604.94 \\
774.32 \\
1360.66\end{array}$ \\
\hline
\end{tabular}

Source: Authors' own calculations based on multiplier analysis

Note:

* Unit is ZAR millions except for the variable 'Production multipliers'.

The analysis of the results indicates that the direct economic impact of spending by the two types of hunters (trophy and biltong) in the regions (in the order of $\mathrm{R} 1.5$ billion for Limpopo, R696 million for the Northern Cape and R655 million for the Free State), produced an additional R1.1 billion (Limpopo), R78 million (Northern Cape) and R705 million (Free State) of indirect and induced impact, giving a total impact for the regions in excess of R2.6 billion (Limpopo), R774.3 million
(Northern Cape) and R1,360.7 million (Free State). This is equivalent to an aggregated production multiplier in the order of 1.78 (Limpopo), 1.11 (Northern Cape) and 2.08 (Free State). The aggregated production multiplier is obtained by dividing the total impact by the direct impact. Therefore, for each rand spent by the two types of hunters in the region, 78 cents (Limpopo), 11 cents (Northern Cape) and 108 cents (Free State) were generated additionally in terms of indirect expenditure. 
One of the elements of the additional valueadded that results from the hunters' spending in the three provinces is employee remuneration, which in turn affects household income. The household income multiplier thus measures the magnitude of changes both to household income and to spending and saving patterns. The impact on low-income households is particularly important, as it can be used to indicate how much hunting contributes to poverty alleviation through the provincial economy. Labour is a key element of the production process. Based on figures from the Limpopo SAM, and using data on the labour force per province relative to the business volume and jobs per activity sector in South Africa for 2006, it was possible to estimate the impact of hunter spending on the provinces' job level. The research found that 17,806 (Limpopo), 9,072 (Northern Cape) and 4,558 (Free State) jobs may depend on hunting, in addition to those of people permanently employed on game farms. Consequently, the absence of hunting would have meant a reduction of 31,436 jobs in these provinces.

\subsection{A regional perspective}

It is evident that the impact of hunting on the local economies of the three provinces under investigation differs significantly, as the following findings show.

First, the impact in Limpopo, R2.6 billion, is the highest for several reasons: $50 \%$ of South Africa's game farms are found here (Eloff, 2002); the largest percentage of hunters, biltong and trophy, 29\%, prefer to hunt here (Lindsey, 2008; Van der Merwe et al., 2011); the most preferred species for hunting, such as kudu, impala, blue wildebeest and warthog, are commonly found here (Lindsey, 2008); and Limpopo borders Gauteng (see Figure 2), which is South Africa's wealthiest area and the province that most of the hunters come from (Warren, 2011). Table 1 shows that hunters' spending in Limpopo on, for example, accom-modation (R184 million), species hunted (R694 million) and daily fees (R46 million) was clearly the highest of the three provinces. It is evident that the size of the overall operation (the number of game farms), the number of hunters, the species available and the geographical location of the market play a significant role in the economic impact of hunting.
Second, the Free State has the highest multiplier of the three provinces, 2.08, which is an indication of better-established forward and backward linkages and, hence, fewer economic leakages. This can be seen by looking at the sectors that benefit most from hunting expenditure - it is evident that the Free State economy favours manufacturing. This province's economy is more balanced than those of Limpopo and the Northern Cape, both of which rely heavily on agriculture.

Third, Limpopo is also the province where the highest number of job opportunities was generated by hunting, namely 17,806 , with the Northern Cape in second place with 9,072. Again, job creation is driven primarily by the number of game farms.

\section{6}

\section{Conclusion}

This article compared the economic impact and significance of hunting from the regional perspective of three key hunting provinces in South Africa, Limpopo, the Northern Cape and the Free State. The findings of the research will contribute to policy formulation, especially for government decisions regarding what products to offer where, and how to create more jobs, as the research confirms that hunting is an activity that generates significant amounts of money and employment. Results also assist game farmers to decide what species to host. Besides considering the factors routinely included in economic impact studies, such as the length of stay, spending per person, the multiplier effect and the number of tourists, this research highlighted geographical location, looking at where game farms are located, how many there were in each area, and what species they offer. These factors were all shown to influence the magnitude of the economic impact.

The research also showed that the size of the hunting industry in a province and its closeness to the main market outperformed the multiplier effect. Despite having the largest multiplier, hunting in the Free State did not have the largest economic impact. This is an important finding, because, in a world where transport costs are constantly on the increase, location will play an ever-increasing role in the 
future of hunting or of any other tourism product.

Limitations of the research are the following: a lack of comprehensive data regarding "other expenditure", such as the cost for travel partners of trophy hunters, as numerous overseas hunters are accompanied by their partners. If this data were available, it would almost certainly have contributed to a higher overall impact by hunting. Due to a lack of data on hunting in other provinces, this study did not determine the overall impact of hunting in all nine provinces of South Africa. Future research should address this shortcoming.

\section{Acknowledgements}

The authors would like to thank the two anonymous reviewers for comments and suggestions, which have contributed to this paper. The usual caveats apply.

The authors would also like to acknowledge the financial assistance of the NRF (National Research Foundation), as, without their contribution, this research would not have been possible.

\section{References}

ASGISA. 2005. Accelerated and shared growth initiative of South Africa. Government Press: Pretoria.

BALDUS, R.D. \& CAULWELL, A.E. 2004. Tourist hunting and its role in development of wildlife areas in Tanzania. Community Wildlife Management Programme. GTZ, Dar es Salaam. July 2004.

BARNES, J.I., NHULEIPO, O., BAKER, A.C., MUTEYAULI, P.I. \& SHIGWEDHA, V. 2009. Wildlife resource accounts for Namibia. DEA Research Discussion Paper No 79. Directorate of Environmental Affairs, Ministry of Environment and Tourism, Windhoek.

BBC RESEARCH AND CONSULTING. 2008. The economic impacts of hunting, fishing and wildlife watching in Colorado. Prepared for Colorado division of wildlife. Colorado: BBC Research and Consulting. BLAKE, A., ARBACHE, J.S., SINCLAIR, M.T. \& TELES, V. 2008. Tourism and poverty relief. Annals of Tourism Research, 35:107-127.

BODDINGTON, C. 2010. What to expect when hunting in South Africa. in P. Flack and J. Neufeld (Eds.) Safari Guide:200-208. Long Beach: Safari Press.

BURGER, L.W., MILLER, D.A. \& SOUTHWICK, R.I. 1999. Economic impact of northern bobwhite hunting in the south-eastern United States. Wildlife Society Bulletin, 27:1010-1018.

CONNINGARTH ECONOMISTS. 2006. Economic Multipliers for the Free State Province. Unpublished research report, Pretoria.

DAMM, G.R. 2005. Hunting in South Africa: facts, risks, opportunities. African Indaba, 3:1-20.

DORRINGTON, S. 2005. The professional hunting industry in South Africa: History and future. African Indaba, $3: 12-13$

DORRINGTON, S. 2007. Hunting in South Africa: The new regulations. African Indaba, 5 3-15.

ELOFF, T. 2002. The economic realities of the game industry in South Africa. Paper presented at the $5^{\text {th }}$ International Wildlife Ranching Symposium, South Africa Game Ranchers Association, South Africa. FREE STATE BUSINESS. 2009. The guide to business and investment in the Free State Province: Home page. Available at: http://www.freestatebusiness.co.za/pls/cms/ti_secout.secout_prov?p_sid=40\&p site_id=169 [accessed 2012-2-19].

HAJNOVICOVA, V. \& LAPISAKOVA, J. 2002. Input-output and SAM multiplier analysis: The Slovak case. Proceedings of the 14th International Conference on the input-output techniques. 10-15 October. Montreal. Canada.

INTERNATIONAL ASSOCIATION OF FISH AND WILDLIFE AGENCIES (IAFWA). 2002. Economic Importance of hunting in America. Washington: IAFWA.

LABOUR FORCE SURVEY. 2006a. Labour Force Survey. South Africa: Free State. Available at: http://www.southafrica-newyork.net/oldconsulate/provinces/freestate.htm [accessed 2012-2-27].

LABOUR FORCE SURVEY. 2006b. South Africa: Northern Cape. Available at: http://www.southafricanewyork.net/oldconsulate/provinces/northerncape.htm [accessed 2012-2-17]. 
LABOUR FORCE SURVEY. 2006c. South Africa: Limpopo province. Available at: http://www.southafricanewyork.net/oldconsulate/provinces/limpopo.htm [accessed 2012-2-27].

LINDSEY, P.A., ROULET, P.A. \& ROMAÑACH, S.S. 2007. Economic and conservation significance of the trophy hunting industry in sub-Saharan Africa. Biological Conservation, 134:455-469.

LINDSEY, P.A. 2008. Trophy hunting in sub-Saharan Africa: Economic scale and conservation significance. in R.D. Baldus, G.R. Damm \& K. Wollscheid (Eds.) Best Practices in Sustainable Hunting - A Guide to Best Practices from around the World:41-47. Blackwell Publishing.

MABUNDA, D. 2008. SANParks and the future of national parks. Africa Geographic, 16: 82-83.

MULDER, A.C. 2011. Motivations of international trophy hunters choose to hunt in South Africa, Master's thesis: Nelson Mandela Metropolitan University, Port-Elizabeth.

NORTHERN CAPE BUSINESS. 2011. A guide to business and investment in the Northern Cape Province. Available at: http://www.northerncapebusiness.co.za/pls/cms/ti_secout.secout_prov?p_sid=1\&p_site_id=164 [accessed 2012-2-19].

NOSS, A.J. 1997. The economic impact of communal net hunting among the BaAka of the Central African Republic. Ecology, 25:71-89.

PYATT, G. \& ROUND, J.I. 1985. SAMs: A basis for planning. World Bank, Washington DC.

RADDER, L. 2005. Motives of international trophy hunters. Annals of Tourism Research, 32:1141-1144. RITCHIE, J.R. \& GOELDNER, C. 1994. Travel, tourism, and hospitality research $\left(2^{\text {nd }}\right.$ ed.) Wiley: London. SAAYMAN, M. 2000. En route with tourism ( $2^{\text {nd }}$ ed.) Institute for Tourism and Leisure Studies: Potchefstroom.

SAAYMAN, M. \& SAAYMAN, A. 2010. Regional development and national parks in South Africa: Lessons learned. Tourism economics, 16:1073-1064.

SAAYMAN, M., VAN DER MERWE, P., ROSSOUW, R. \& OBERHOLZER, S. 2009. A socio-economic impact study of the Northern Cape hunting industry. Potchefstroom: Institute for Tourism and Leisure Studies.

SAAYMAN, M., VAN DER MERWE, P. \& ROSSOUW, R. 2011a. The economic impact of hunting in the Northern Cape Province. South African Journal of Wildlife Research, 41:120-133.

SAAYMAN, M., VAN DER MERWE, P., ROSSOUW, R. \& OBERHOLZER, S. 2011b. A socio-economic impact study of the Limpopo Province hunting industry. Potchefstroom: Institute for Tourism and Leisure Studies.

SAMUELSSON, E. \& STAGE, J. 2007. The size and distribution of the economic impacts of Namibian hunting tourism. South African. Journal of Wildlife Research, 37:41-52.

SCHOLTZ, M., VAN DER MERWE, P. \& SAAYMAN, M. 2010. The national profile and economic impact of biltong hunters in South Africa. Potchefstroom: Institute for Tourism and Leisure Studies.

SA PLACES (SOUTHERN AFRICA PLACES CC). 2012. South Africa accommodation finder. Available at: http://places.co.za [accessed 2012-2-28].

SOUTH AFRICAN YEARBOOK. 2011. Republic of South Africa: Tourism. Available at: http://www.south africa-network.net/conselate/yearbook_2011.html [accessed 2012-3-9].

STATISTICS SOUTH AFRICA. 2012. Census 2011: Provinces at a glance. Pretoria: Statistics South Africa TALJAARD, P.R. 2007. The macro economy and irrigation agriculture in the Northern Cape Province of South Africa. Unpublished PhD thesis, University of the Free State, Bloemfontein, South Africa.

VAN DER MERWE, P. 2004. Game farms as sustainable ecotourism attractions, PhD Thesis: Potchefstroom University for Christian Higher Education (now North West University, Potchefstroom).

VAN DER MERWE, P. \& SAAYMAN, M. 2005. Game farms as sustainable ecotourism attractions. Koedoe, 48:1-10.

VAN DER MERWE, P., SAAYMAN, M. \& KRUGELL, W.F. 2004. Factors that determine the price of game. Koedoe, 47:105-113.

VAN DER MERWE, P., SAAYMAN, M. \& KRUGELL, W.F. 2007. The determinants of the spending of biltong hunters. South African Journal of Economics and Management Sciences, 10:184-194.

VAN DER MERWE, P., SCHOLTZ, M. \& SAAYMAN, M. 2011. The national profile and economic impact of biltong hunters in South Africa. Potchefstroom: Institute for Tourism and Leisure Studies. 
VAN HOVEN, W. 2005. Ecotourism and game ranching: Why it works. Paper presented at Ecotourism South Africa Confex, Johannesburg.

WAGNER, J. E. 1997. Estimating the economic impacts of tourism. Annals of Tourism Research, 24 : 591-608.

WARREN, R. 2011. A spending model for biltong hunters, PhD thesis: North-West University, Potchefstroom. 